\title{
Análise de atividade de água em alimentos armazenados no interior de granjas avícolas*
}

\begin{abstract}
DENISE MARQUES GARCIA
Carlos Tadeu Pippi Salle (Orientador - UFRGS)

Banca: Antônio Mário Penz Júnior (UFRGS), Caciano Zapata (UFRGS), Luciana Ruschel dos Santos (UPF)

$\mathrm{Na}$ avicultura algumas integrações têm a prática de estocar as dietas por vários dias dentro da granja e muitas vezes, essas são submetidas a condições inadequadas de armazenamento. Os dados relacionados aos fatores ambientais, especialmente temperatura e umidade relativa do ambiente, tempo de estocagem e principalmente atividade de água ( $\mathrm{a}_{\mathrm{w}}$ ) do alimento, são fatores importantes que influenciam o crescimento fúngico e produção de micotoxinas no substrato, tornandose importantes para o estabelecimento de um programa de prevenção e controle deste agente (ORRIS, 1999). Este trabalho objetivou analisar a atividade de água em dietas animais para verificar o potencial de crescimento fúngico e a forma de armazenamento do produto. Desta forma, foi estudada a atividade de água da dieta comercial de empresa de integração avícola no Rio Grande do Sul, antes da entrega ao criador e no último dia de armazenamento, nas diferentes estações do ano. Assim, buscou-se contribuir para a verificação das condições de conservação do alimento e dos possíveis riscos de contaminação, auxiliando na prevenção de fungos e toxinas de importância avícola e com reflexos na saúde pública.Também foi determinada a umidade e a isoterma de adsorção destes alimentos, para auxiliar na compreensão sobre a forma de armazenamento. Pelos resultados encontrados ficou confirmado o aumento da atividade de água após o período de armazenamento da dieta, correspondendo ao valor de 0.681 de $\mathrm{a}_{\mathrm{w}}$ na fábrica e 0.693 de $\mathrm{a}_{\mathrm{w}}$ na granja. No entanto, os valores de atividade de água não estavam inseridos nos limites mínimos de crescimento fúngico ( 0.78 de $\mathrm{a}_{\mathrm{w}}$ ) e produção de aflatoxinas ( 0.86 de $\mathrm{a}_{\mathrm{w}}$ ). Houve correlação linear positiva entre atividade de água e umidade da ração, tanto na fábrica quanto na granja. A isoterma de adsorção apresentou aumento da umidade com o aumento da atividade de água. Não houve correlação entre atividade de água e ppb de aflatoxina encontrados nas dietas.
\end{abstract}

Descritores: atividade de água, isoterma de adsorção, dieta, controle de aflatoxinas.

Apresentada: 22 março 2004

*Dissertação de Mestrado n. 374 (Especialidade: Patologia Aviária). 49f. Programa de Pós-graduação em Ciências Veterinárias - UFRGS Porto Alegre/RS. CORRESPONDÊNCIA: D.M. Garcia [ctps@ufrgs.br] 


\title{
Analysis of water activity on food stored in the interior of poultry farm**
}

\author{
DENISE MARQUES GARCIA \\ Carlos Tadeu Pippi Salle (Adviser - UFRGS)
}

Committee: Antônio Mário Penz Júnior (UFRGS), Caciano Zapata (UFRGS), Luciana Ruschel dos Santos (UPF)

In some poultry industry, diets remain stored for days in the farm and, many times, it is subjected to inappropriate storage conditions. The information related to the environmental conditions, especially temperature and environment relative humidity, storage time and, mainly, food water activity $\left(\mathrm{a}_{\mathrm{w}}\right)$ are important agents that influence fungal growth and mycotoxins production on the substratum, becoming important to the establishment of a program to prevent and control this agent (ORRIS, 1999). This researchwork had as it principal objective to analyze the water activity to verify the potential of fungal growth and the way that the product is stored. In this way, it was studied the water activity of commercial diet in a company of the poultry integration in the state of Rio Grande do Sul, Brazil, before the delivery at the farm and the last day of storage, in different seasons. For this reason, this assignment sought to verify the conditions of food preserving and possible risks of contaminations, serving as preservation of fungi and toxins of avian importance and with reflexes in public health. It was determined the humidity and the adsorption isotherm of this feed to assist in the compreension about the way this feed is stored. For the results it was confirmed the increase on water activity after the period of feed storage, corresponding at $0,681 \mathrm{a}_{\mathrm{w}}$ before the delivery at the farm and 0,693 $\mathrm{a}_{\mathrm{w}}$ the last day of storage at the farm. However, the values of water activity were not inserted on the minimum limits of fungal growth $\left(0,780 \mathrm{a}_{\mathrm{w}}\right)$ and aflatoxins production $\left(0,86 \mathrm{a}_{\mathrm{w}}\right)$. There was a positive linear correlation between the water activity and the humidity of the diet, both at the fact view and at the farm. The adsorption isotherm presented an increase in humidity, with the increase in water activity. There wasn't correlation between the water activity and ppb of aflatoxin meet in diets.

Key words: water activity, adsorption isotherm, diets, aflatoxins control.

**Masther's Thesis \# 374 (Field: Avian Pathology). 49p. Graduate Program in Veterinary Sciences, Faculdade de Veterinária, Universidade Federal do Rio Grande do Sul (UFRGS), Porto Alegre/Brazil. CORRESPONDENCE: D.M. Garcia [ctps@ufrgs.br]. 